\title{
4. OBSERVATION OF FOREARC SEAFLOOR DEFORMATION ALONG THE NORTH D'ENTRECASTEAUX RIDGE-NEW HEBRIDES ISLAND ARC COLLISION ZONE FROM NAUTILE SUBMERSIBLE ${ }^{1}$
}

\author{
H. Gary Greene, ${ }^{2}$ Jean-Yves Collot, ${ }^{3}$ Bernard Pelletier, ${ }^{4}$ and Serge Lallemand ${ }^{5}$
}

\begin{abstract}
Observations made from a dive (Dive 4) of the French submersible Nautile along the deformation front associated with the North d'Entrecasteaux Ridge-New Hebrides Island Arc collision zone indicated strong compressional deformation and dewatering of an accretionary mass. Outcrops of highly tectonized nannofossil clay, chalk, and calcareous volcanic siltstone were examined and found to be smoothed and grooved from persistent downslope transport of sediment eroded from the upper forearc slope and islands of the arc. These sediments were directed from the nearshore and upper slope areas by a submarine canyon that is disrupted in mid-slope by the growing deformational front. From mid-slope, sediments are transported by sheet flow through many swales and gullies to the flat seafloor at the base of the slope, where the sediments are deposited as turbidites. Fluvial-like processes appear to be occurring along the deformation front as indicated by scour holes and depressions.
\end{abstract}

\section{INTRODUCTION}

The New Hebrides Island Arc extends from the Santa Cruz Islands in the north to Hunter-Matthews islands in the south and in its central region is colliding with the d'Entrecasteaux Zone (DEZ) (Fig. 1). The DEZ is composed of two ridges, the North d'Entrecasteaux Ridge (NDR) and the South d'Entrecasteaux Chain (SDC) and is being carried eastward by the Australia-India plate to the New Hebrides Trench where it is being subducted along a Benioff zone that dips $70^{\circ}$ (Pascal et al., 1978; Chung and Kanamori, 1978; Isacks et al., 1981; Marthelot et al., 1985; Louat et al., 1988). Here the relative convergence rate is $10 \mathrm{~cm} / \mathrm{yr}$ (Minster and Jordan, 1978) with the plate motion directed at $\mathrm{N} 76^{\circ} \mathrm{E} \pm 11^{\circ}$ (Isacks et al., 1981). The arc-ridge collision has obliterated the physiographic expression of the trench (Karig and Mammerickx, 1972) and caused rapid uplift of the Western Belt islands of Espiritu Santo and Malakula.

Rapid uplift (on the order of 3.6-6.0 mm/yr) and eastward tilting of the islands of Espiritu Santo and Malakula have been estimated based on the study of elevated coral reefs (Taylor et al., 1980, 1985, 1987; Jouannic et al., 1980). The Wousi Bank, located off the south-central part of western Espiritu Santo Island (Fig. 2A) and bounded on the northern and southern sides with steep scarps and normal faults, has been elevated 1.5-2.5 $\mathrm{km}$ by subduction of the NDR (Collot and Fisher, 1991) and tilted to the north. Eastward extension of the NDR beneath the accretionary wedge of the forearc is substantiated by seismicity data in the form of intermediate depth earthquakes (Marthelot et al., 1985), as well as gravity data (Collot and Fisher, 1988), magnetic data (Collot and Fisher, 1991), and multichannel seismic reflection data (Fisher et al., 1986). Because the convergence angle of the NDR is slightly oblique $\left(14^{\circ}\right)$ to the axial trend

\footnotetext{
${ }^{1}$ Collot, J.-Y., Greene, H. G., Stokking, L. B., et al., 1992. Proc. ODP, Init, Repts., 134: College Station, TX (Ocean Drilling Program). U.S.A.

U.S. Geological Survey, 345 Middlefield Rd., Menlo Park, CA 94025,

${ }^{3}$ Laboratoire de Geodynamique Sous-Marine, ORSTOM, B.P. 48, 06230 Villefranche-sur-Mer, France.

${ }^{4}$ Institut Français de Recherche Scientifique pour le Développement en Coopération, ORSTOM, B.P.A. 5, Noumea, New Caledonia.

5 Université Pierre et Marie Curie, 75252 Paris Cedex, France.
}

$\left(\mathrm{N} 20^{\circ} \mathrm{W}\right)$ of the arc, the NDR-island-arc intersection moves northward at about $2.5 \mathrm{~cm} / \mathrm{yr}$ (Collot and Fisher, 1991). Fisher et al. (1991), on the basis of the Seabeam and multichannel seismic data, describe the impingement area of the NDR on the forearc slope as a trenchward-bulging mass of accretionary material actively undergoing rapid uplift and lateral tectonic movement.

At the point of collision the NDR is $40 \mathrm{~km}$ wide and the deformation on the forearc slope is restricted to about $20 \mathrm{~km}$ on either side of the ridge's flanks, producing a fairly narrow $(80-\mathrm{km})$ deformation zone (Daniel et al., 1986; Collot and Fisher, 1991). The NDR-New Hebrides Island Arc collision zone has been divided into three sections: (1) a northern section undergoing compression, (2) a central section undergoing uplift, and (3) a southern section undergoing dilation and mass wasting (Collot and Fisher, 1991).

In March 1989, a series of manned Nautile submersible dives were made along the forearc slope of the New Hebrides Island Arc, within the DEZ collision zone, to examine and evaluate the seafloor geology in preparation for Ocean Drilling Program (ODP) Leg 134. Seven dives concentrated in two areas (along the flanks and northern base of Wousi Bank and along the arcward side of Bougainville Guyot) were made for this site survey (Fig. 2A). These dives were part of the French investigation SUBPSO1 organized by the Institut Français de Recherche Scientifique pour le Développement en Coopération (ORSTOM) and the Institut Français de Recherche pour l'Exploitation de la Mer (IFREMER) to study the processes associated with the DEZ collision (Collot et al., 1989). IFREMER's submersible Nautile, used in this study, can operate to a depth of $6 \mathrm{~km}$. Global positioning system (GPS) of navigation and previously obtained Seabeam bathymetric data (Daniel et al., 1986) were used.

We report the findings of one of the dives (Dive 4) made along the northern base of Wousi Bank, at the intersection of the northern NDR's flank and the forearc slope-the northern or compressional zone of Collot and Fisher (1991). We divide the dive traverse into two parts (flat-floored and slope) and relate the observational data to results of drilling at ODP Sites 827 and 829.

\section{DIVE OBSERVATIONS}

Dive 4 surveyed the lower northwestern slope of Wousi Bank in the northern section of the NDR-arc collision zone, 


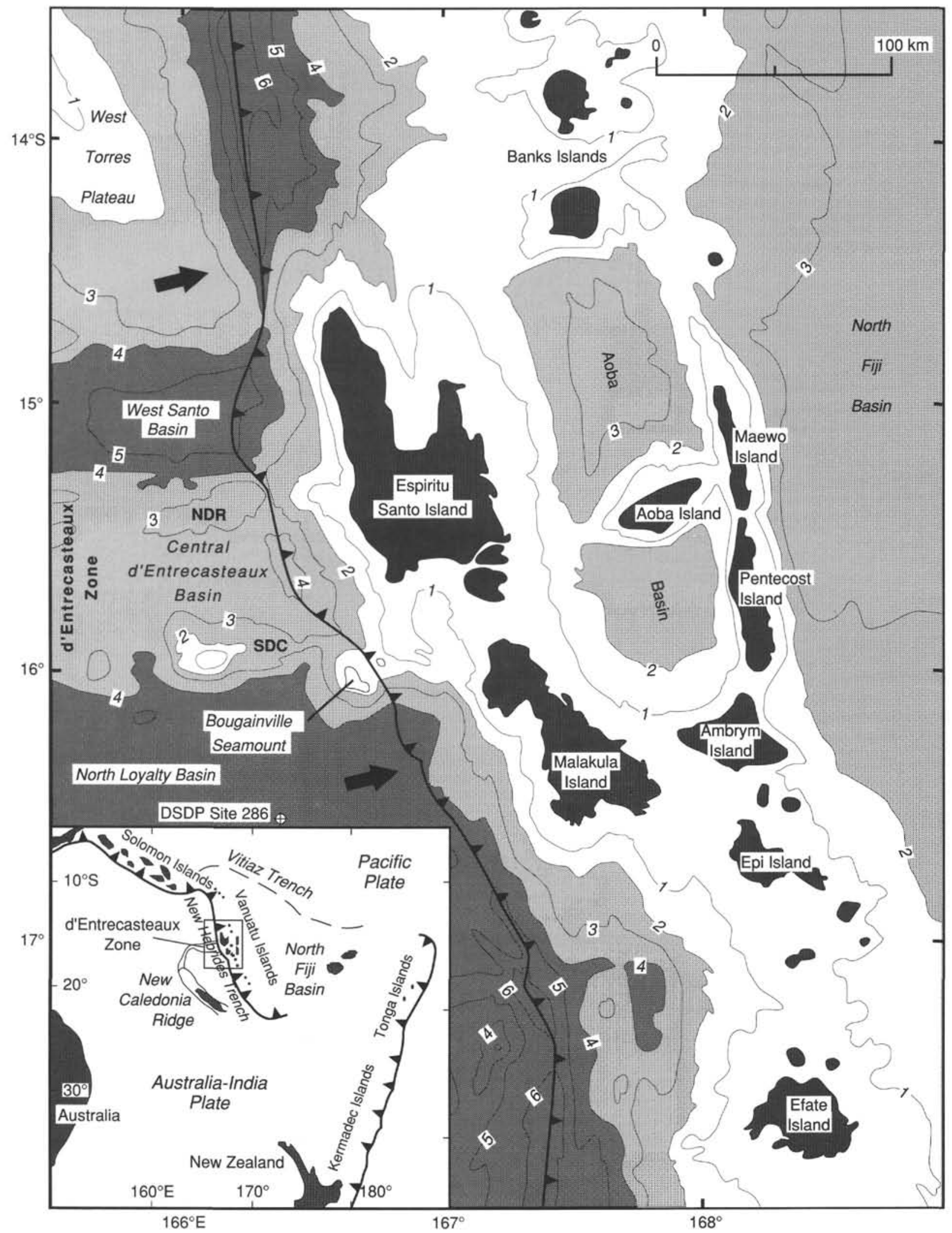

Figure 1. Map showing regional physiographic elements of the New Hebrides Island Arc. NDR = North d'Entrecasteaux Ridge; SDC $=$ South d'Entrecasteaux Chain. Bathymetric contours are in kilometers. 
where Collot and Fisher (1991) describe a seaward-bulging accretionary mass that diverges $45^{\circ}$ eastward from the regional arc trend, probably representing a rotated block (Fig. 3). These authors describe the topography of the area as consisting of numerous ridges, canyons, and valleys on the order of 50-200 m high and $500-3000 \mathrm{~m}$ wide. These features trend obliquely $\left(\mathrm{N} 60^{\circ} \mathrm{W}\right)$ across the arc slope, with the upper slope morphology composed of a network of submarine gullies that converge to a major arcuate submarine canyon that defines the boundary between the northern and central sections of the collision zone (Daniel et al., 1986; Collot et al., 1989; Collot and Fisher, 1991). In this area repeated mobilization of the accreted rocks occur from the collisional movement of the NDR and much material is transported down the slope to the trench (Collot and Fisher, 1991).

The dive traverse started at a depth of $5358 \mathrm{~m}$ and terminated at a depth of $4523 \mathrm{~m}$ (Fig. 4). The traverse consisted of two parts: (1) a flat-bottom traverse along a general course of $150^{\circ}$ true on the floor of the West Santo Basin, near the seafloor trace of the subduction zone, and (2) a slope traverse up the steep forearc slope $\left(\sim 40^{\circ}\right.$ average), along a course of $115^{\circ}$ true, near the boundary between the northern and central NDR collision zone. Both photographic documentation and detailed stratigraphic sampling were undertaken during this dive. Detailed lithologic description, age determination, and discussion of the samples are presented in a separate paper (Collot et al., unpubl. data). ${ }^{6}$ Navigation on the seafloor was poor because the initial location of Nautile at the start of the dive could not be determined. Also, the dive transect does not agree with the Seabeam data, but covered much steeper terrane than that exhibited on Seabeam maps.

\section{Flat-Bottom Traverse}

Bedforms observed along the flat-bottom traverse indicate strong currents. The bottom was composed primarily of randomly scattered boulders, cobbles, and pebbles (Fig. 5). Interspersed with the boulders were rippled sand patches and stringers of gravel. Few benthic or encrusting fauna were seen except for some bluish-gray holothurians and small bluishgray sea anemones attached to wood debris.

Rocks observed along the traverse were transported from locations upslope. These rocks consisted primarily of gray to whitish-gray, rounded to subrounded or flat, tabular, volcanic sandstone to tuff-like boulders, cobbles, and pebbles. Other lithologies consisted of whitish-gray, rounded volcaniclastic rocks, volcanic breccias, and dark-gray volcanic rocks. Many rocks were concentrated in patches and stringers. Scour depressions containing cobble, pebble, and gravel lag deposits surrounded most of the boulders. Generally, the seafloor consisted of flat, tabular rocks, locally imbricated, that appeared very much like desert pavement. Stringers of gravel and rippled sand trailed south from boulders.

Patches ( $2 \mathrm{~m}$ wide, $3 \mathrm{~m}$ long, $6 \mathrm{~cm}$ thick, on average) of heavily rippled sand were common and often interspersed between boulders and rock piles (Fig. 5). Dark constituents (volcanic sand or heavy minerals) were concentrated in the ripples of the sand patches. Distinct, sharp-edged slip faces were observed. These slip faces appear to define the advancing front of the sand patches and generally faced south; trailing tapered ends were strung out toward the north. These rippled sand patches seemed to have been actively migrating from north to south. The scour depressions around boulders,

${ }^{6}$ Collot, J.-Y., Lallemand, S., Pelletier, B., Eissen, J.-P., Glaçon, G., Fisher, M. A., Greene, H. G., Boulin, J., Daniel, J., and Monzier, M. Geology of the d'Entrecasteaux-New Hebrides island arc collision: results from a deep-sea submersible survey (submitted to Tectonophysics). current striae, sand and gravel stringers, and rippled sand patches all indicated a general north-to-south flow of a strong current, although no such current was observed during the dive.

In addition to the strong bottom-current regime, the area also appears to be periodically subjected to debris flow and turbidite deposition. The existence of rounded, obviously transported boulders, rock, and gravel piles, oriented in a parallel, linear fashion with occasional wood debris, indicated the transport of terrestrial and upper slope deposits down the forearc slope by debris flow. The morphology and bedforms observed on this traverse may represent deposition from gravity flow.

\section{Slope Traverse}

At a water depth of $5170 \mathrm{~m}$ we encountered the base of a cliff, composed of reddish-brown clayey nannofossil ooze and chalk. The face of the cliff was smooth and grooved as if polished by sediment transport down the face (Fig. 6). A change in ripple mark orientations from generally east-west to generally north-south at the base of the slope also supported the existence of an east-to-west downslope current, rather than the north-to-south flowing current evidenced on the flat seafloor. The general appearance of the outcrop was that of a melange or fault gouge. Further examination of the outcrop suggested that it may be a tectonite or a fractured and sheared front of the transpressional deformation lobe described by Collot and Fisher (1991).

An almost continuous outcrop of the reddish-brown nannofossil ooze and chalk extended $647 \mathrm{~m}$ in height from 5170 to $4523 \mathrm{~m}$ (Fig. 4), maintaining an average slope of about $25^{\circ}-30^{\circ}$ and locally exhibiting steep $\left(80^{\circ}-90^{\circ}\right)$ faces. Along this traverse the outcrop alternated from steep faces to flat or gently sloping ledges or shelves. Based on detailed observations and sampling the outcrop was divided into three units: (1) a lower reddish-brown nannofossil ooze and chalk with silty clay and mixed sedimentary rocks with foraminifers ( 1200 m thick), (2) an intermediate gray calcareous, volcanic siltstone unit ( $\sim 500 \mathrm{~m}$ thick), and (3) an upper reddish-brown clayey nannofossil ooze and chalk unit ( $\sim 250 \mathrm{~m}$ thick) (Fig. 4).

The lower ooze and chalk unit is sheared and fractured with white mineralized veins and sills cutting through the outcrop (Fig. 7). Locally the face of the outcrop located beneath a distinct shear zone is coated with a thin layer of a whitish mineral that can also be seen filling the cracks and fractures within the outcrop. This mineralization is possibly caused by. dewatering of the accretionary mass. In many places chunks of ooze and chalk have broken away along fractures and cracks; incipient breakaways were identified along the many fractures and cracks observed in the outcrop. Shearing and fracturing in the outcrop appeared to be more intense near the contact between the lower ooze and chalk and overlying calcareous volcanic siltstone units. Some horizontal or bedding shears were observed, suggesting lateral movement, perhaps along bedding planes (Fig. 8). A smooth, grooved, and fluted surface to the outcrop is common on the shelves and ledges (Fig. 9). At the base of the steep faces are rippled sands and debris or scree deposits that receive sediment by steeply dipping debris chutes (Fig. 10).

Bedded laminae of alternating black, brown, and white mud or clay was observed near the top of the upper ooze and chalk unit. Bedding here strikes generally $010^{\circ}$ and dips $70^{\circ} \mathrm{E}$, similar to attitudes observed on weak bedding elsewhere in this unit. Just below the contact with the lower ooze and chalk and overlying siltstone unit, a flattish, gently dipping ledge of nannofossil chalk is smoothed, grooved along bedding planes, and exhibits a scour hole (Fig. 11). Badland-like topography is 
A

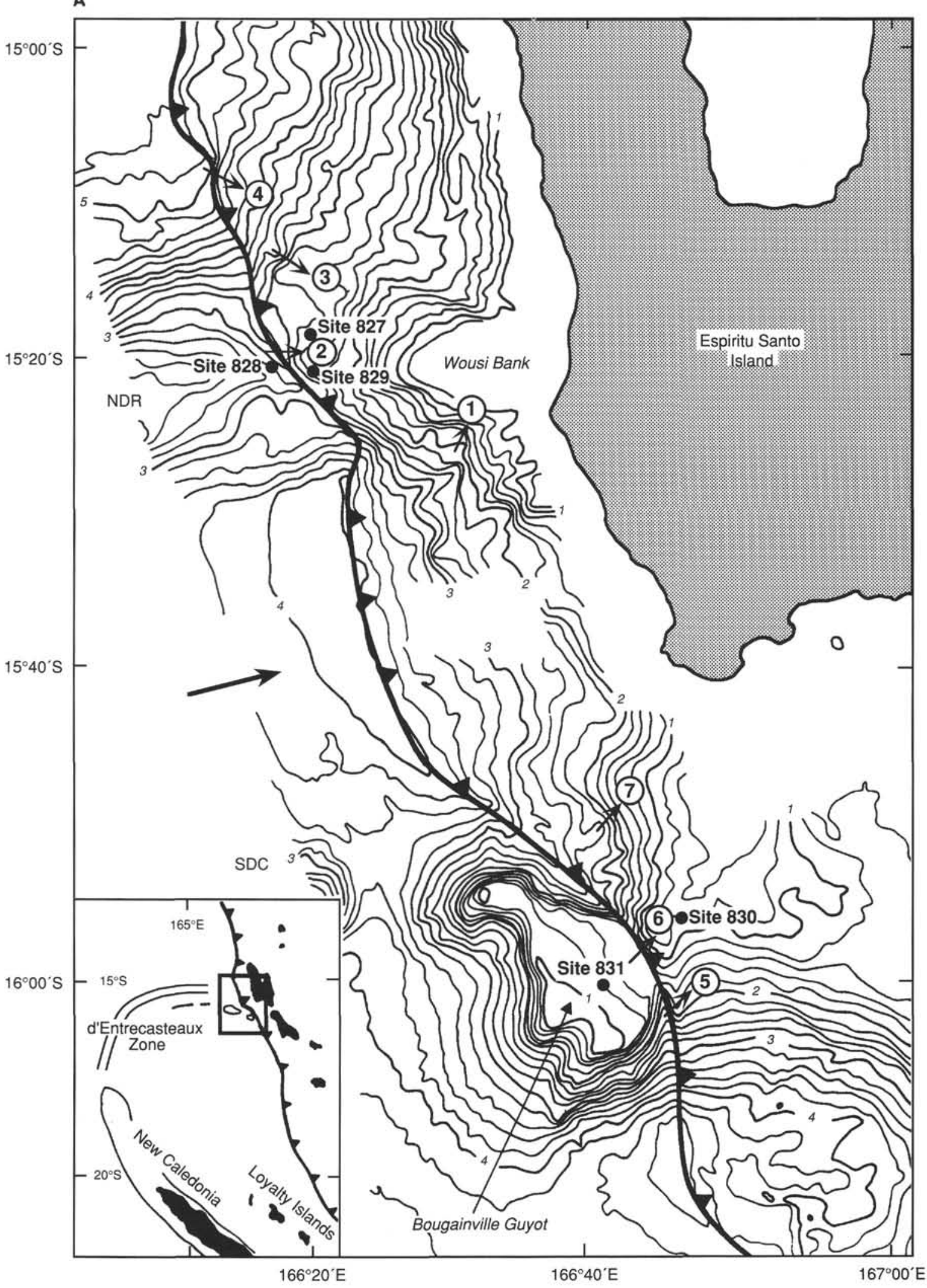

Figure 2. A. Map showing Nautile dive sites 1-7 along the forearc area where the d'Entrecasteaux Zone is colliding with the central New Hebrides Island Arc. These dives were part of the French (ORSTOM/IFREMER) SUBPSO1 investigation. $\mathrm{NDR}=$ d'Entrecasteaux Ridge; SDC = South d'Entrecasteaux Chain. Bathymetric contours are in kilometers. Arrows with numbers indicate approximate location of Nautile dives. Dots are Leg 134 drill sites. B. Detailed Seabeam map showing approximate Nautile traverse. Bathymetric contours are in meters. 


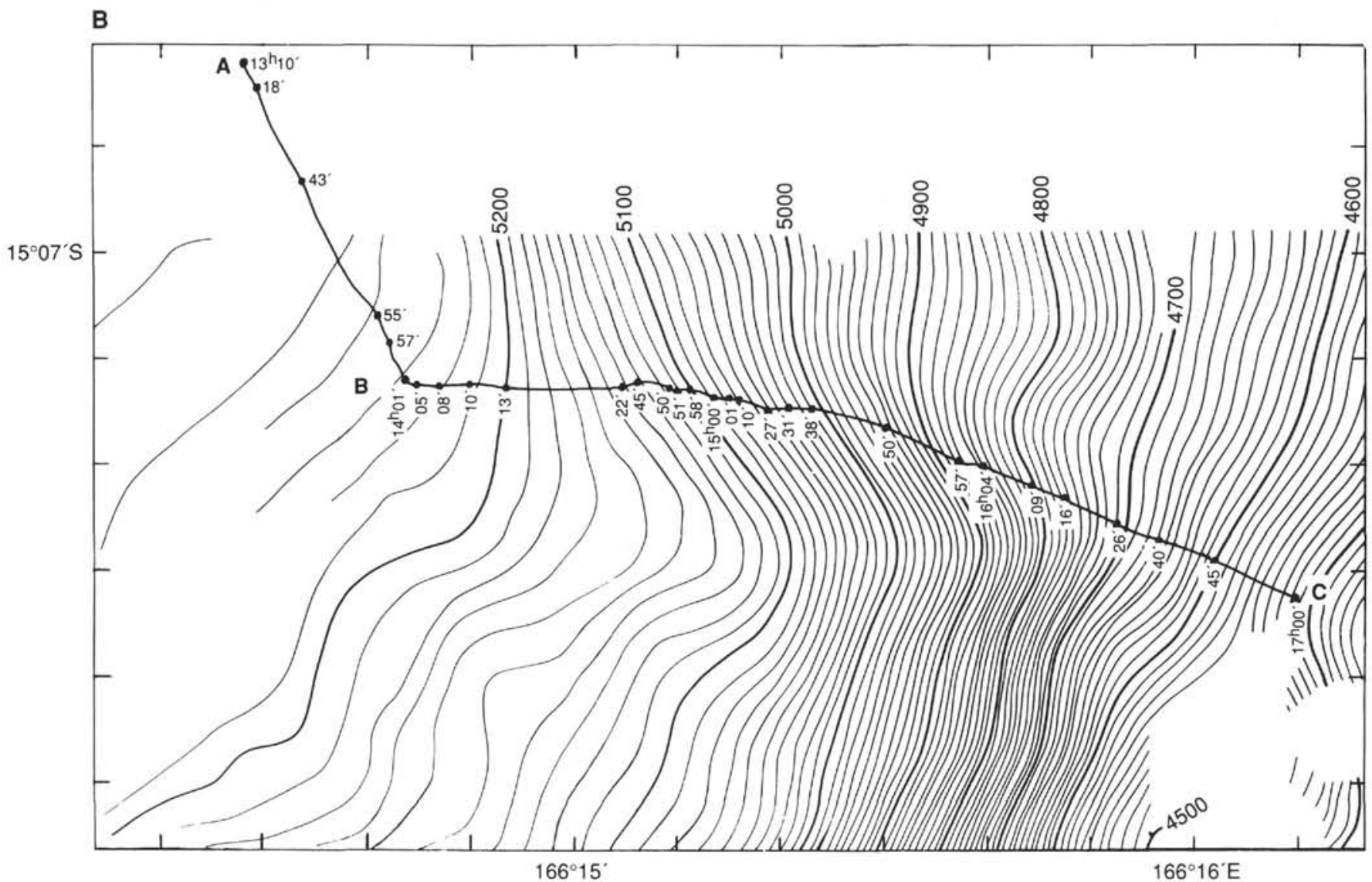

Figure 2 (continued).

present and displays crested ridges and steep V-shaped gullies.

At a water depth of about $4626 \mathrm{~m}$, the lithology of the outcrop changes to a hard, gray, blocky calcareous volcanic siltstone with beds ranging from 1 to $3 \mathrm{~m}$ in thickness. Beds appear to strike $010^{\circ}$ at a $70^{\circ} \mathrm{E}$ dip. The basal part of this unit is sheared and fractured, and in places, slickensides were observed along bedding planes. The central part of the unit appeared relatively undisturbed by shearing and fracturing. In one location, debris cones, scree, slopes, and gully-and-ridge topography were also observed. Near the upper part of this unit, shearing and fracturing were extensive (Fig. 12), and near the contact, cliffs give way to more gentle scree-covered slopes.

The upper reddish-brown ooze and chalk unit appears in outcrop to be similar to the lower ooze and chalk unit. The upper unit is sheared and fractured, cut by white veins and dikes, and thinly laminated in places, although it has a more blocky nature than observed in the lower unit, and bedding seems to dip steeply eastward. The outcrop is smooth with grooves and flutes and high-relief gully-and-ridge topography, indicating that it is easily eroded.

\section{CONCLUSIONS}

The flat seafloor that fronts the deformation wedge associated with the collision of the NDR with the New Hebrides Island Arc is covered with debris eroded from the arc and carried down the forearc slope by turbidity currents. Evidence of strong currents and turbidite deposition was found.

The traversed slope appears to have been tectonized. The strong shearing and fracturing suggest that uplift and possible lateral transport of rock have deformed the slope's structure and bedding. This appears to be the deformation front caused by the impingement of the NDR upon the forearc slope. Fresh cracks and fractures near the edges of the cliffs and the lack of a well-defined downslope continuation of the canyons that debouch upon the upper part of the outcrop provide evidence of continued motion of the deformation front.

The smooth surface of the outcrop, grooves and flutes, and the gullies and ridges, all indicate active sediment transport across the face of the outcrop. A well-defined canyon upslope appears to terminate at the top of the outcrop traversed by Nautile. This canyon most likely supplies considerable sediment that is carried downward along the face of the outcrop by sheet(?) flow and through many gullies and swales. Grooves, chutes, and gulleys form easily in the highly erodible tuffaceous rocks. Fluvial-like processes appear to affect the area: a well-developed scour hole containing gravel, cobbles, and boulders appears to have formed by circular scouring by current flow at a depth of $4780 \mathrm{~m}$, similar to the development of scour holes in streams on land. No benthic communities were seen along the traversed slope, indicating active and continuous sediment transport across the face of the outcrop.

Holes drilled at Site 829 penetrated the deformation front $\sim 18 \mathrm{~km}$ southeast of the Dive 4 traverse and revealed a series of thrust faults similar to the shear zones observed during the dive. Structural analyses of cores from Site 829 indicate severe compressional deformation. Pore-fluid concentrations along the thrust faults with relatively dry interthrust fault rocks suggest dewatering of the deformation front along thrust planes. This is consistent with observation made during Dive 


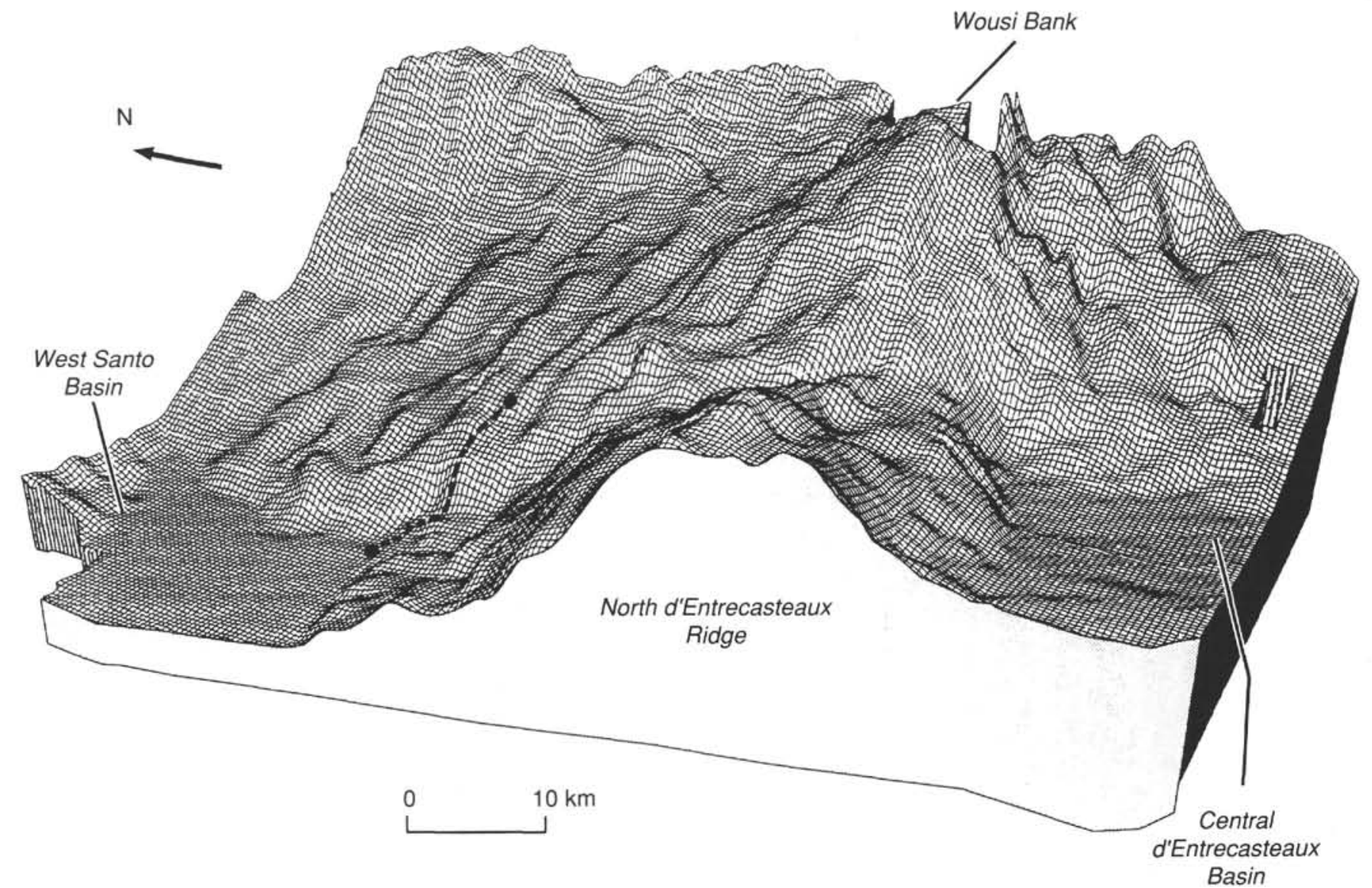

Figure 3. Mesh diagram of Seabeam bathymetry, generated from IFREMER data, of the collision zone between the North d'Entrecasteaux Ridge and central New Hebrides Island Arc, showing deformation associated with the NDR collision. Vertical exaggeration is 5:1. Dashed line is approximate traverse of Nautile during Dive 4. Modified from Collot and Fisher (1991).

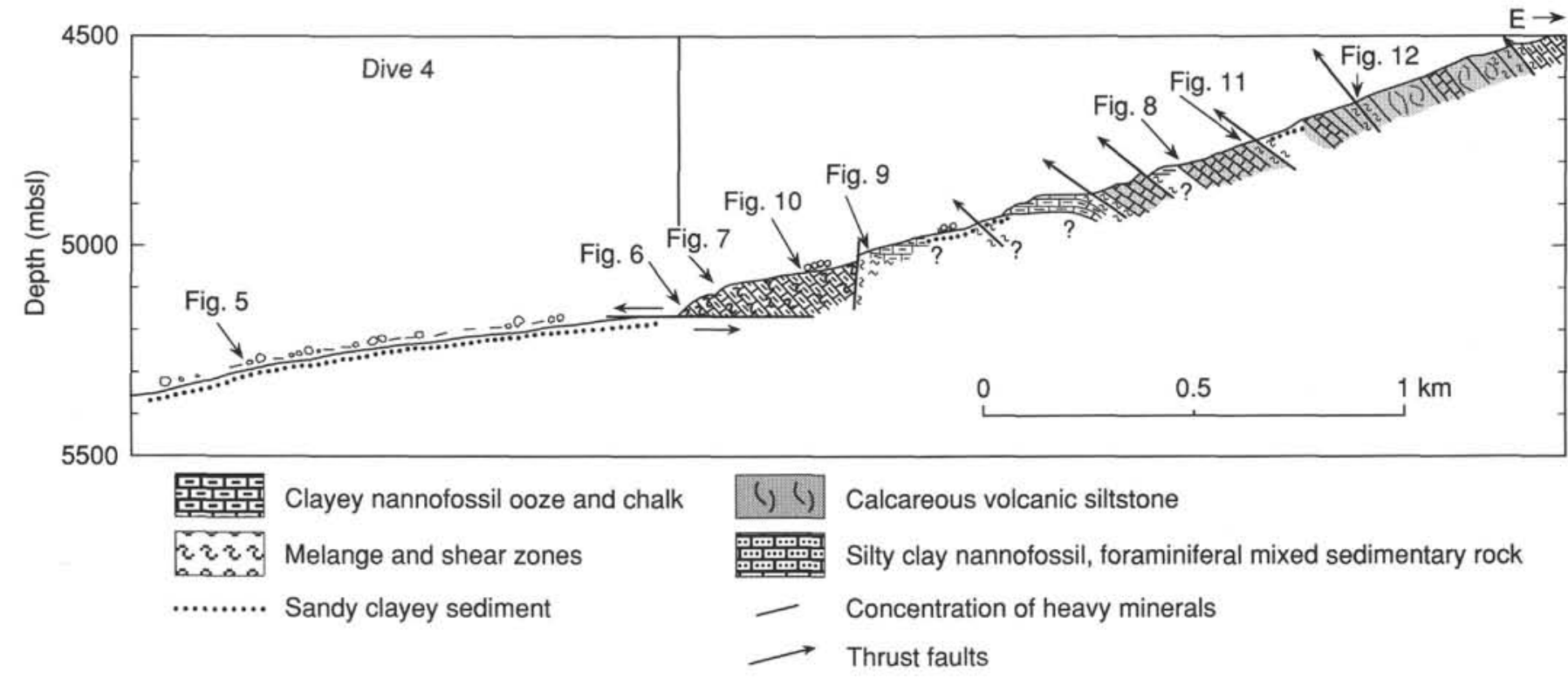

Figure 4. Schematic cross-section of Nautile Dive 4 transect up the forearc slope of the central New Hebrides Island Arc. Arrows with numbers indicate location of photographs shown in the following figures. No vertical exaggeration. Approximate location of cross-section shown in Figures 2B and 3. Modified from Collot et al. (unpubl. data). 


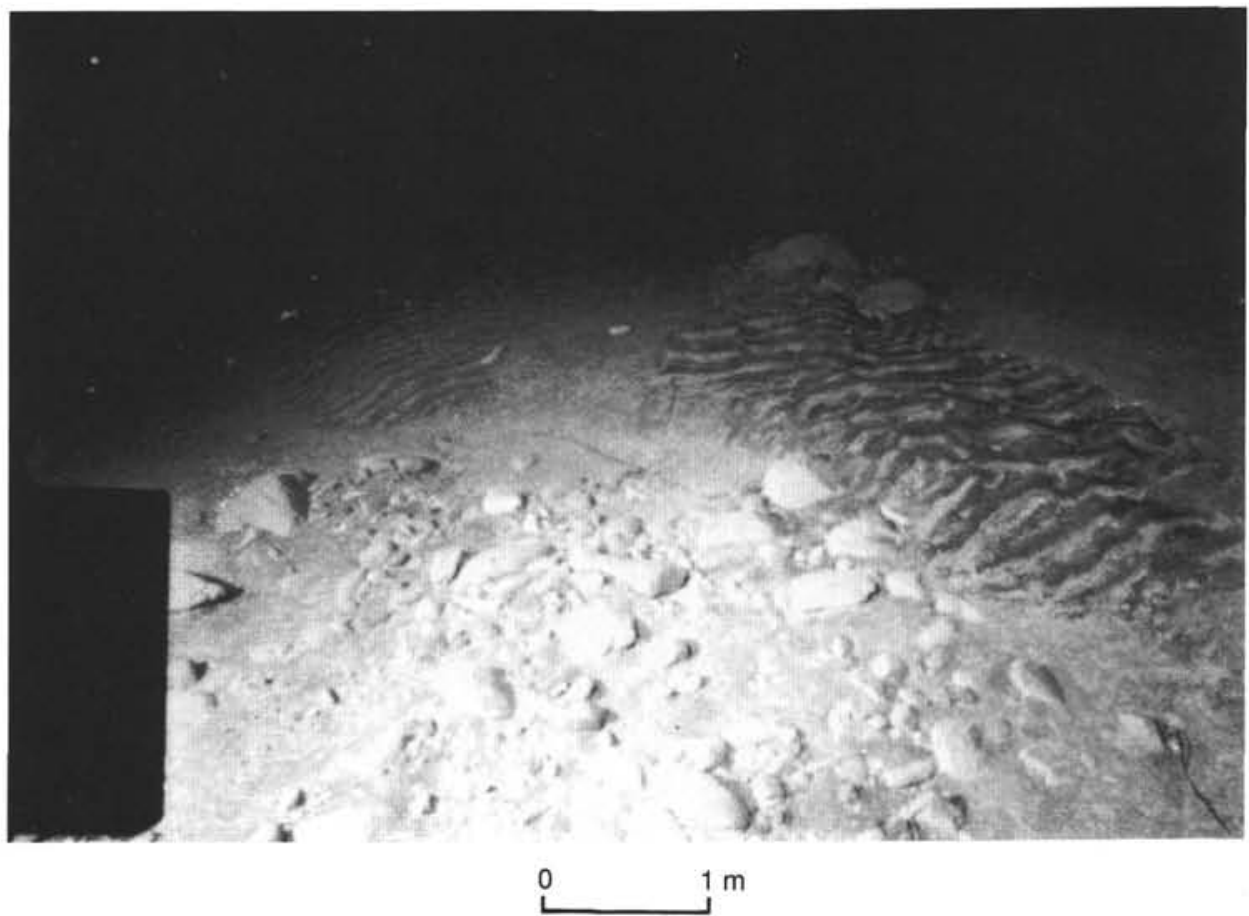

Figure 5. Photograph taken from Nautile showing fine- to coarse-grained material deposited on the flat seafloor in front of the North d'Entrecasteaux Ridge deformation zone. Depth is 5303(?) meters below sea level (mbsl). Indication of strong bottom currents is illustrated in rippled sand patches. View toward the north.

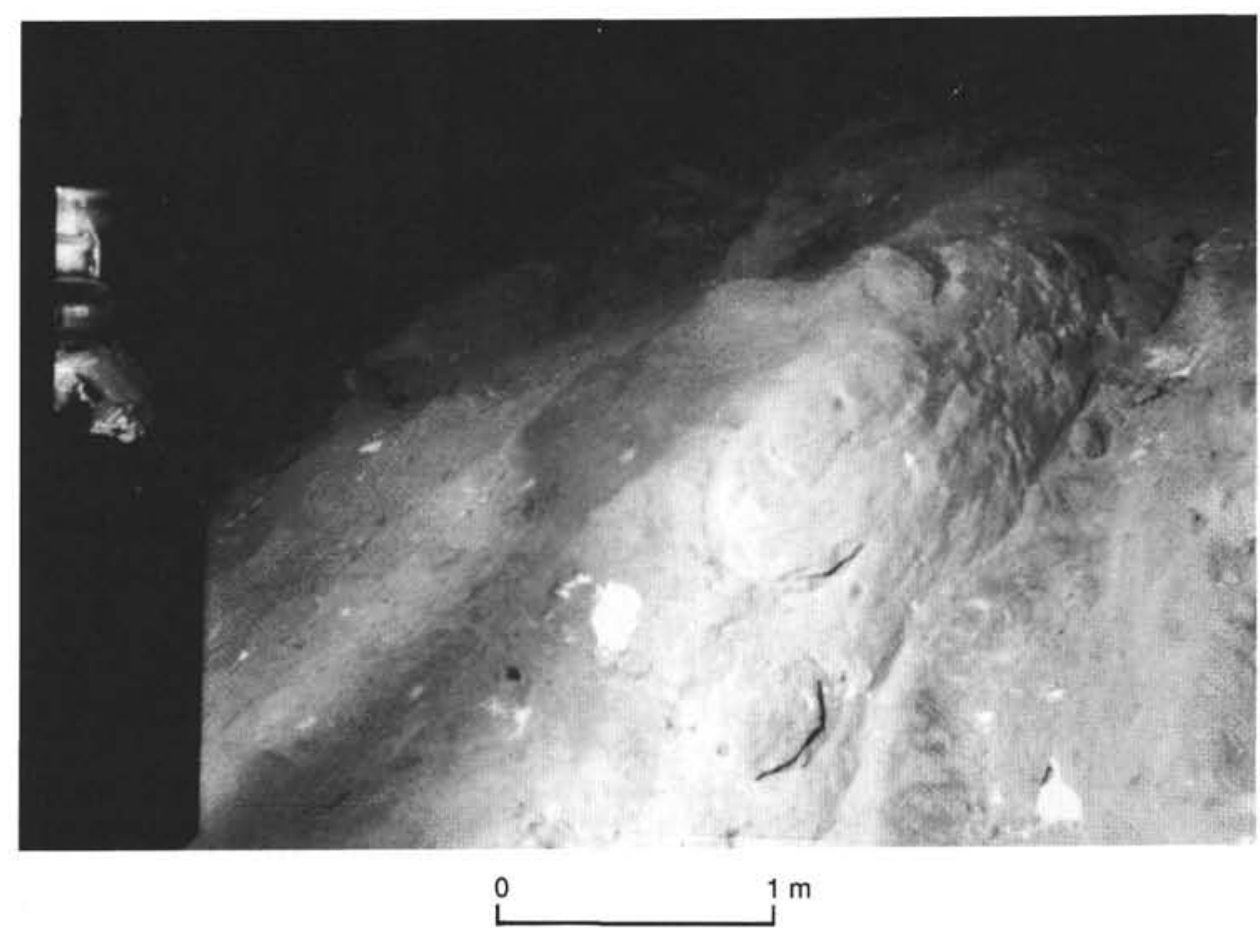

Figure 6. Photograph taken from Nautile at a depth of $5155 \mathrm{mbsl}$ showing smoothed and grooved, red clayey nannofossil ooze and chalk deformation found at the collision zone between the North d'Entrecasteaux Ridge and central New Hebrides Island Arc. View toward the east. 


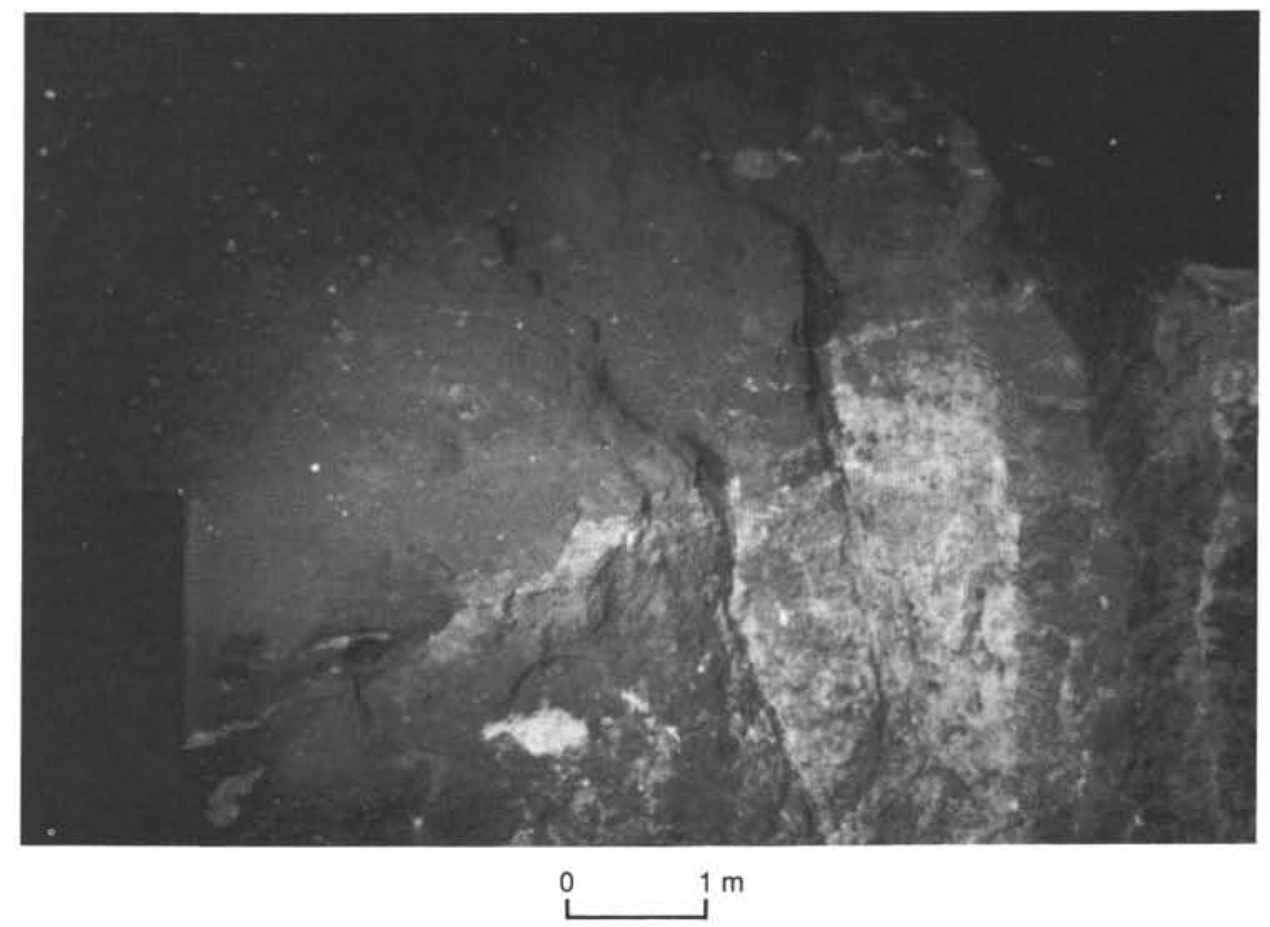

Figure 7. Photograph taken from Nautile at a depth of $5103 \mathrm{mbsl}$ showing steep relief of deformation front and extensive mineralization beneath a low-angle bedding (thrust) fault probably resulting from compressional dewatering of the sediments. View toward the northeast.

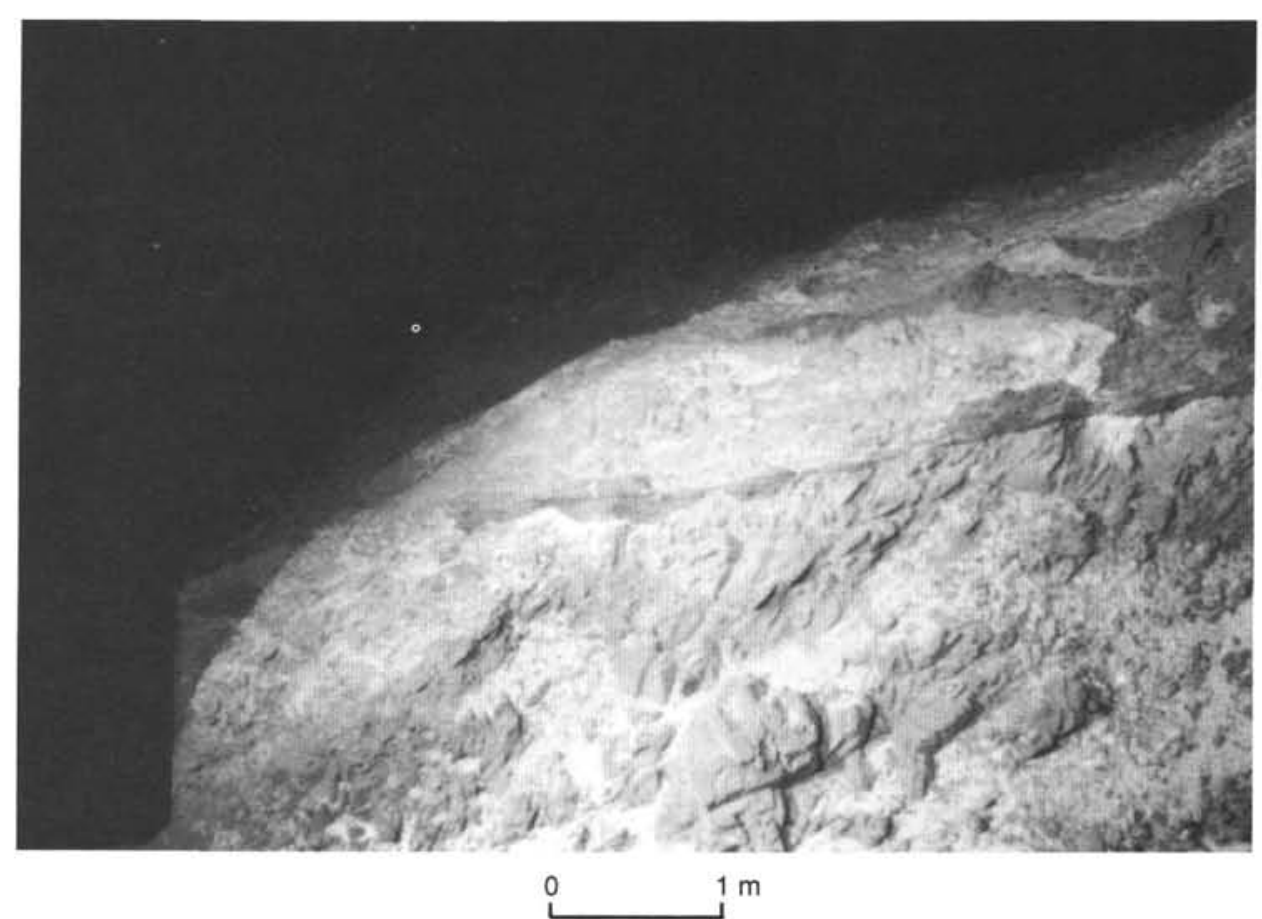

Figure 8. Photograph taken from Nautile at a depth of $4810 \mathrm{mbsl}$ showing horizontal shear plane in red clayey nannofossil ooze and chalk of deformation front. View toward the northeast. 


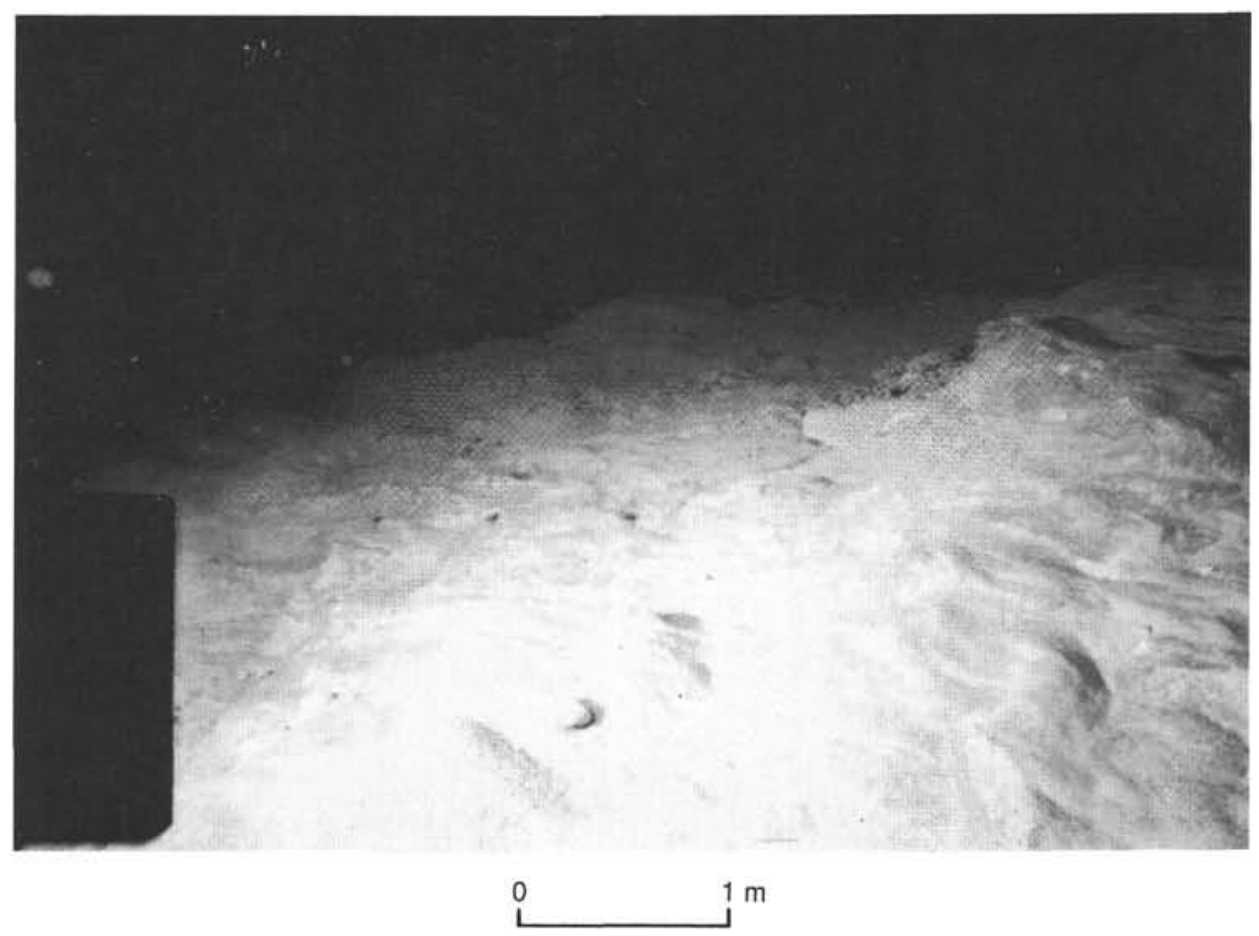

Figure 9. Photograph taken from Nautile at a depth of $5004 \mathrm{mbsl}$ showing smooth and grooved surface of flat clayey nannofossil ooze and chalk shelf surface in deformation front. View toward the north.

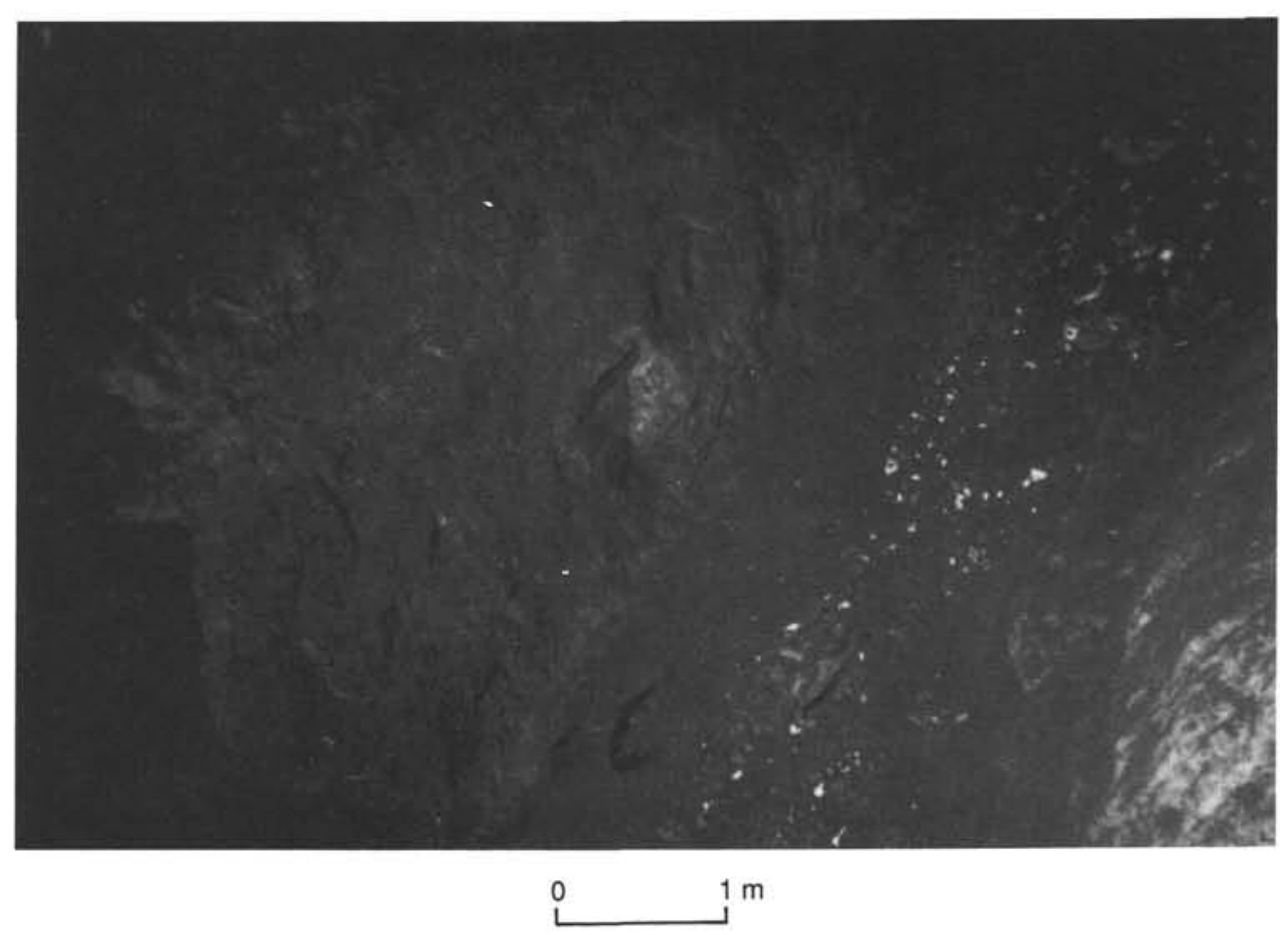

Figure 10. Photograph taken from Nautile at a depth of $5153 \mathrm{mbsl}$ showing debris chute eroded into a steep face of the deformation front. View toward the east(?).

4 of whitish minerals beneath a shear zone (Fig. 7), which are interpreted to have been deposited during the interaction of seawater with pore fluids.

We conclude that the collision of the DEZ with the New Hebrides Island Arc has in places sheared and fractured forearc rocks. In addition, a distinct deformation front consisting of reddish-brown clayey nannofossil ooze and chalk (Oligocene and Miocene), showing thrust wedges, of younger (Pliocene and Pleistocene) calcareous volcanic siltstone (Collot et al., unpubl. data), suggests that the NDR is readily and rapidly deforming the forearc during collision and subduction. 


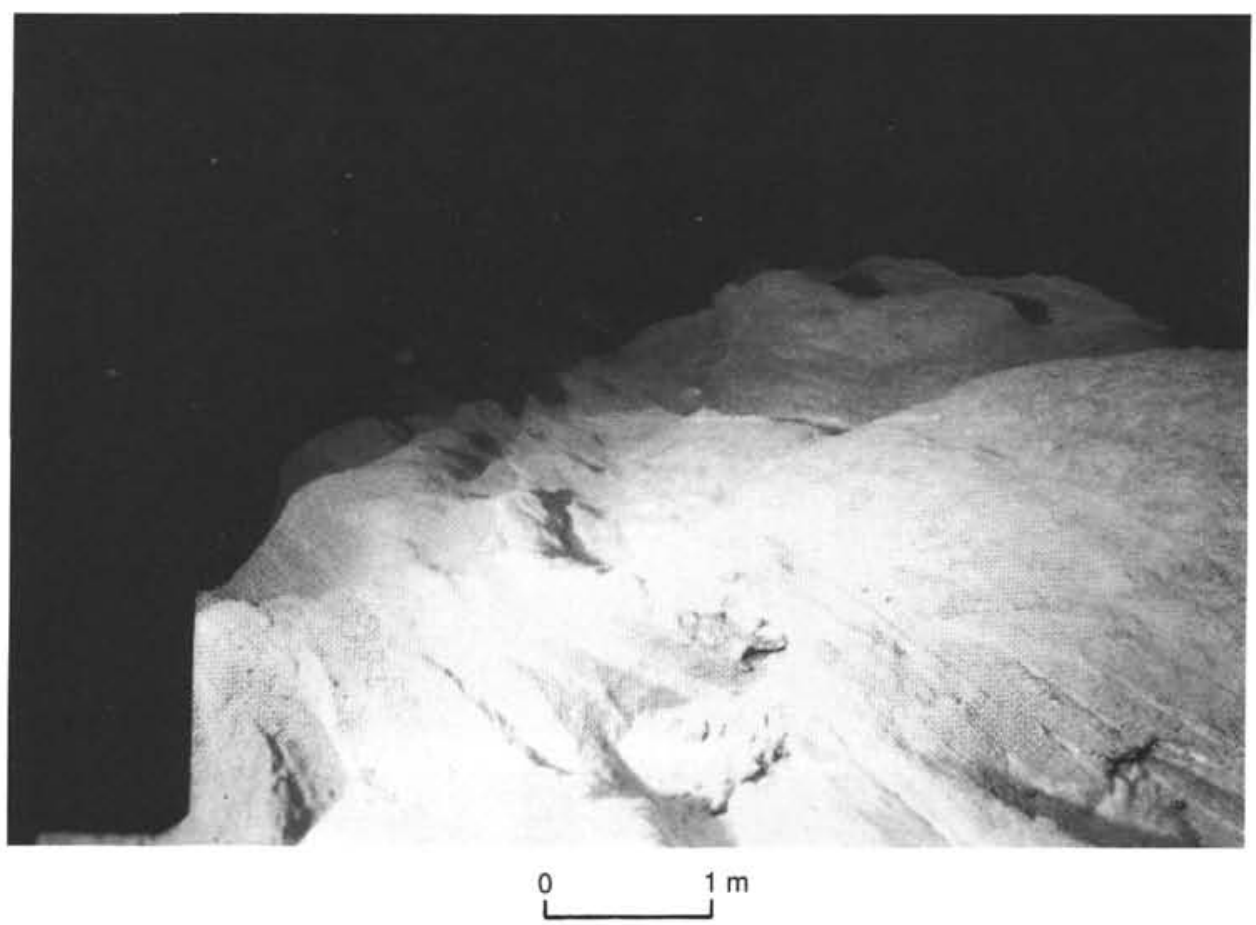

Figure 11. Photograph taken from Nautile at a depth of $4780 \mathrm{mbsl}$ showing smooth and grooved stratified calcareous volcanic siltstone surface with gravel-filled scour hole on a flat shelf in the deformation front. Scour holes are similar to potholes eroded on terrestrial stream and river beds. View toward the northeast.

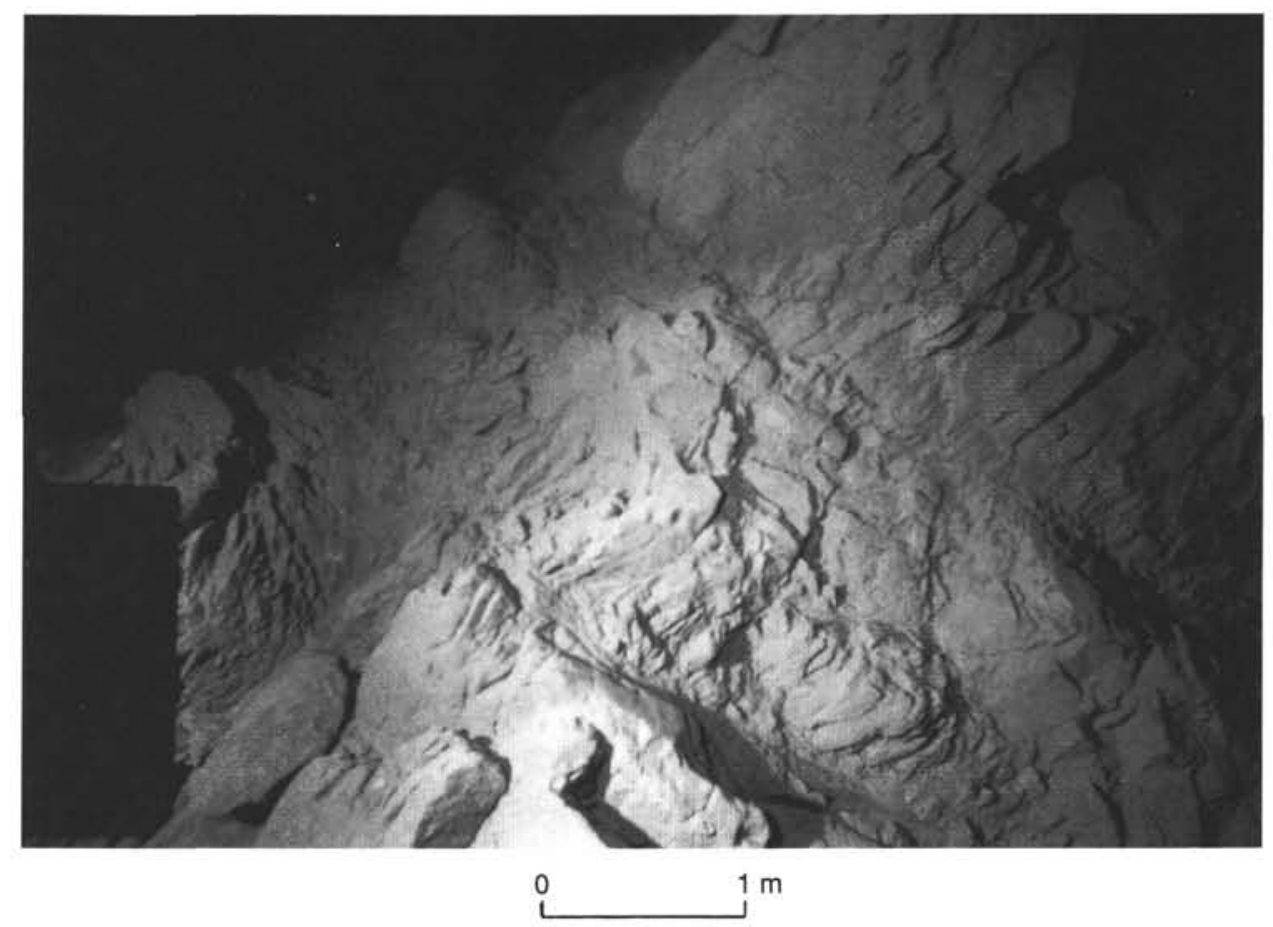

Figure 12. Photograph taken from Nautile at a depth of $4650 \mathrm{mbsl}$ showing eastward-dipping sheared calcareous siltstone and sandstone in the upper part of the deformation front. Several different shears can be seen and appear to be aligned along bedding planes. View toward the north. 
Badland topography, channels, chutes, gullies, scour holes, depressions, and polished and grooved surfaces, all indicate active downslope sediment transport. Near Wousi Bank, the deformation wedge has destroyed and distorted the lower channel of a small submarine canyon, thus causing wide distribution of canyon-transported sediment at midslope. Many features observed suggest that fluvial-like activity is occurring at depth.

\section{REFERENCES}

Chung, W. Y., and Kanamori, H., 1978. A mechanical model for plate deformation associated with aseismic ridge subduction in the New Hebrides arc. Tectonophysics, 50:29-40.

Collot, J.-Y., and Fisher, M. A., 1988. Crustal structure, from gravity data, of a collision zone in the central New Hebrides Island Arc. In Greene, H. G., and Wong, F. L. (Eds.), Geology and Offshore Resources of Pacific Island Arcs-Vanuatu Region. Circum-Pac. Counc. Energy and Miner. Resour., Earth Sci. Ser., 8:125-140.

1991. The collision zone between the North d'Entrecasteaux Ridge and the New Hebrides Island Arc. Part 1: Seabeam morphology and shallow structure. J. Geophys. Res., 96:44574478.

Collot, J.-Y., Pelletier, B., Boulin, J., Daniel, J., Eissen, J.-P., Fisher, M. A., Greene, H. G., Lallemand, S., and Monzier, M., 1989. Premiers résultats des plongées de la campagne SUBPSO1 dans la zone de collision des rides d'Entrecasteaux et de l'arc des Nouvelles-Hébrides. C. R. Acad. Sci. Ser. 2, 309:1947-1954.

Daniel, J., Collot, J.-Y., Monzier, M., Pelletier, B., Butscher, J., Deplus, C., Dubois, J., Gérard, M., Maillet, P., Monjaret, M. C., Récy, J., Renard, V., Rigolot, P., and Temakon, S. J., 1986. Subduction et collision le long de l'arc des Nouvelles-Hébrides (Vanuatu): résultats préliminaires de la campagne SEAPSO (leg 1). C. R. Acad. Sci. Ser. 2, 303:805-810.

Fisher, M. A., Collot, J.-Y., and Geist, E. L., 1991. The collision zone between the North d'Entrecasteaux Ridge and the New Hebrides Island Arc. Part 2: structure from multichannel seismic data. $J$. Geophys. Res., 96:4479-4495.

Fisher, M. A., Collot, J.-Y., Smith, G. L., 1986. Possible causes for structural variation where the New Hebrides Island arc and the d'Entrecasteaux zone collide. Geology, 14:951-954.

Isacks, B. L., Cardwell, R. K., Chatelain, J. L., Barazangi, M., Marthelot, J.-M., Chinn, D., and Louat, R., 1981. Seismicity and tectonics of the central New Hebrides island arc. In Simpson, D. W., and Richards, P. G. (Eds.), Earthquake Prediction: An International Review. Am. Geophys. Union, Maurice Ewing Ser., 4:93-116.

Jouannic, C., Taylor, F. W., Bloom, A. L., and Bernat, M., 1980. Late Quaternary uplift history from emerged reef terraces on Santo and Malekula Islands, central New Hebrides island arc. Tech. Bull.-U. N. Econ. Soc. Comm. Asia Pac., Comm. Co-ord. Jt. Prospect Miner. Resour. South Pac. Offshore Areas, 3:91-108.

Karig, D. E., and Mammerickx, J., 1972. Tectonic framework of the New Hebrides island arc. Mar. Geol., 12:187-205.

Louat, R., Hamburger, M., and Monzier, M., 1988. Shallow and intermediate-depth seismicity in the New Hebrides Arc: constraints on the subduction process. In Greene, H. G., and Wong, F. L. (Eds.), Geology and Offshore Resources of Pacific Island Arcs-Vanuatu Region. Circum-Pac. Counc. Energy and Miner. Resour., Earth Sci. Ser., 8:329-356.

Marthelot, J.-M., Chatelain, J. L., Isacks, B. L., Cardwell, R. K., and Coudert, E., 1985. Seismicity and attenuation in the central Vanuatu (New Hebrides) islands: a new interpretation of the effect of subduction of the d'Entrecasteaux fracture zone. J. Geophys. Res., 90:8641-8650.

Minster, J. B., and Jordan, T. H., 1978. Present-day plate motions. J. Geophys. Res., 83:5331-5354.

Pascal, G., Isacks, B. L., Barazangi, M., and Dubois, J., 1978. Precise relocations of earthquakes and seismotectonics of the New Hebrides Island arc. J. Geophys. Res., 83:4957-4973.

Taylor, F. W., Frohlich, C., Lecolle, J., and Strecker, M. R., 1987. Analysis of partially emerged corals and reef terraces in central Vanuatu arc: comparison of contemporary coseismic and nonseismic events with Quaternary vertical movements. J. Geophys. Res., 92:4905-4933.

Taylor, F. W., Isacks, B. L., Jouannic, C., Bloom, A. L., and Dubois, J., 1980. Coseismic and Quaternary vertical tectonic movements, Santo and Malekula Islands, New Hebrides island arc. J. Geophys. Res., 85:5367-5381.

Taylor, F. W., Jouannic, C., and Bloom, A. L., 1985. Quaternary uplift of the Torres Islands, northern New Hebrides frontal arc: comparison with Santo and Malekula islands, central New Hebrides frontal arc. J. Geol., 93:419-438.

\section{Ms 134A-104}

